\title{
Klima-deroute \\ - klodens stigende feber
}

\section{Af geolog Klaus Petersen}

Jordens fossile brændsler (kul, olie og gas) er aflejret gennem hundrede millioner af år og indgår som en naturlig del af den meget langsomme oplagrings- og udvekslingsproces af organiske kulstofforbindelser i kulstofkredsløbet. Hvad mon der vil ske, hvis man brænder adskillige milliarder tons kulstof af i løbet af blot 200 år?

Se det er netop det, ved vi er ved at finde ud af i noget, der ligner menneskehedens største selvskabte miljøkatastrofe. Kloden har fået kuldioxid-feber, og den er hastigt stigende.

\section{Som for $\mathbf{5 5}$ millioner år siden?}

Jordens klima styrer mere og mere sandsynligt mod en tilstand, som Jordens sidst oplevede i Eocæn for 55 mio. år siden. Med kraftigt stigende kuldioxidindhold i atmosfæren og dermed stigende global temperatur sætter de resulterende klimaforandringer for alvor deres aftryk i stadig mere ødelæggende omfang. Iskapperne smelter, oversvømmelser, tørker, orkaner og hedebølger opleves nu, og vil opleves, steder som ellers

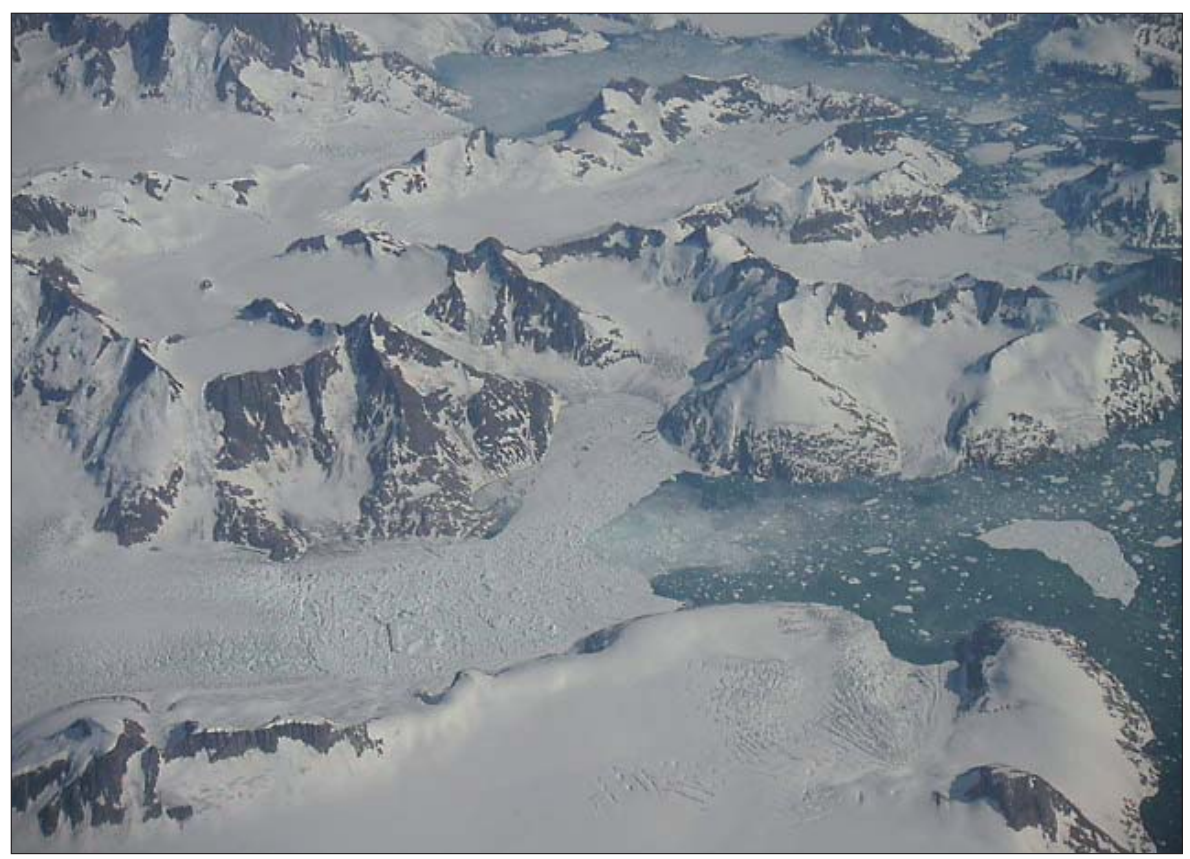

Kcelvning af isbjerge foran en udløbsgletscher fra Indlandsisen i Østgrønland. (Foto: Jacob Yde, Geologisk Institut, Aarhus Universitet)

"normalt" er klimatisk stabile. Strudsepolitik og ignorance er nogle af hovedingredienserne bag de manglende afværgehandlinger, der måske ellers kan redde kloden fra et alvorligt hedeslag.

\section{Opvågnen}

Erkendelsen af, at noget er "helt galt" med klimaet, førte med verdenstopmøde i Rio 1992 (FN klimakonvention) og senere i Kyoto 1997 (Kyoto-protokollen) til de

\section{Klimasystemets inerti}

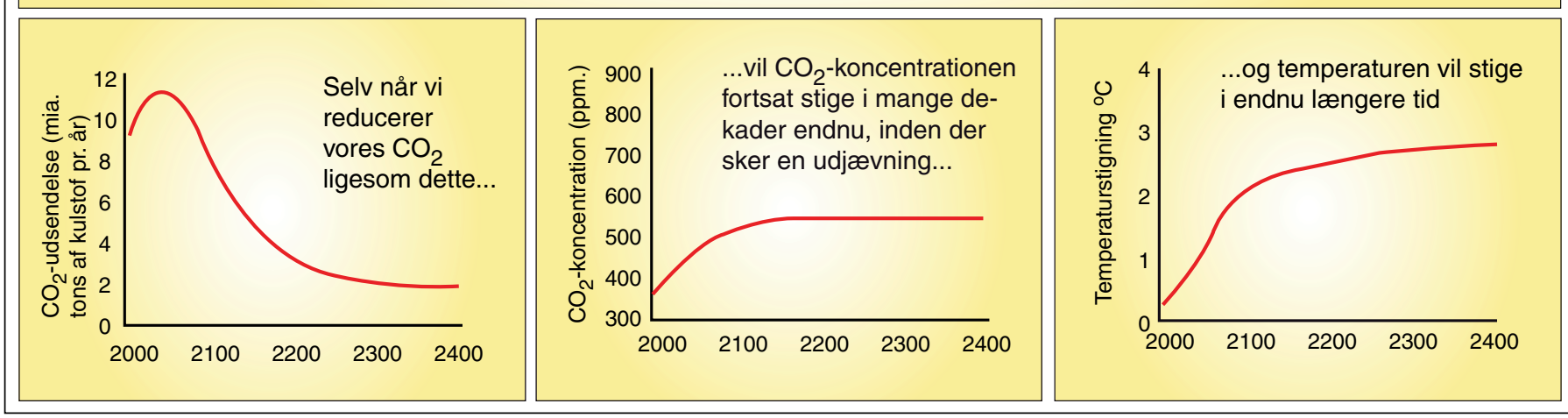

Kurverne viser, at klimasystemet (kulstofkredsløbet) reagerer meget langsomt på selv en kraftig reduktion i udslippet af CO ${ }_{2}$ Tre vigtige konklusioner drages:

1. Koncentrationen af $\mathrm{CO}_{2}$ vil blive ved med at stige i op mod 100 år, og der kan gå omkring 300 år før, blot en stabilisering kan opnås.

2. Temperaturen vil fortsat stige i indtil flere århundreder, før en stabilisering eller faldende trend kan opnås.

3. Havniveauet vil ligeledes forscette med at stige i flere århundreder endog i op til mere end 1.000 år pga. den fortsatte isafsmeltning.

(Grafik: UVH Modificeret efter Henson, 2006, og IPPC Scientific report, 2001) 
første spæde skridt mod egentlige aftaler og handlinger, som skulle begrænse $\mathrm{CO}_{2}$ udslippet og dermed bremse den stigende globale temperatur. Desværre er Kyotoprotokollen ikke ratificeret af alle herunder USA, som pt. er den største udleder af $\mathrm{CO}_{2}$. Endvidere var Kyoto-aftalens mål ikke synderligt ambitiøst. Man kunne kun enes om en reduktion af udslippet på 5,2\% i gennemsnit frem til 2012 i forhold til 1990 niveauet - desværre blev Kyoto-protokollen ikke ophøjet til "international lov" før omkring år 2000, hvor mange lande i mellemtiden havde forøget deres udslip betydeligt - og stadig gør det! Især Kina og Indien er i gang med at fyre kraftigt op for kulkraftværkerne.

Såfremt en reduktion af $\mathrm{CO}_{2}$-udslippene skal have en afgørende virkning på temperaturen, må der skæres meget mere drastisk ned - Selvom alt $\mathrm{CO}_{2}$-udslip stoppede nu, vil det tage op mod 100 år, før vi alene bare får bremset stigningen og når et stabilt eller faldende indhold. Dette skyldes inertien i klimasystemet (kulstofkredsløbet) samt "holdbarheden" af drivhusgasserne. Hvad værre er, at temperaturen antageligt vil holde sig på det forhøjede niveau i op mod flere hundrede år på trods af et "øjeblikkeligt stop" for $\mathrm{CO}_{2}$-udledningen - og at havniveauet derfor også vil blive ved med at stige pga. den fortsatte afsmeltning.

\section{Grumme fremtidsudsigter}

Dette er yderst skræmmende perspektiver, som kræver handling nu - ikke kun for vores skyld, men mere for de kommende generationer - vores løb kan meget vel være kørt, og vi vil i de følgende årtier komme til at opleve de menneskeskabte klimaforandringer som overvejende negative: Begrænsende for samfundsudviklingen, trussel for miljøet, sundheden og levestandarden. På lidt længere sigt (50-200 år) kan konsekvensen blive omfattende folkevandringer, måske ligefrem krige, der udløses af den stigende ørkendannelse, mangel på drikkevand, hungersnød, stigende havniveau samt langt flere ekstreme vejrfænomener (kraftig nedbør, orkaner og tørker).

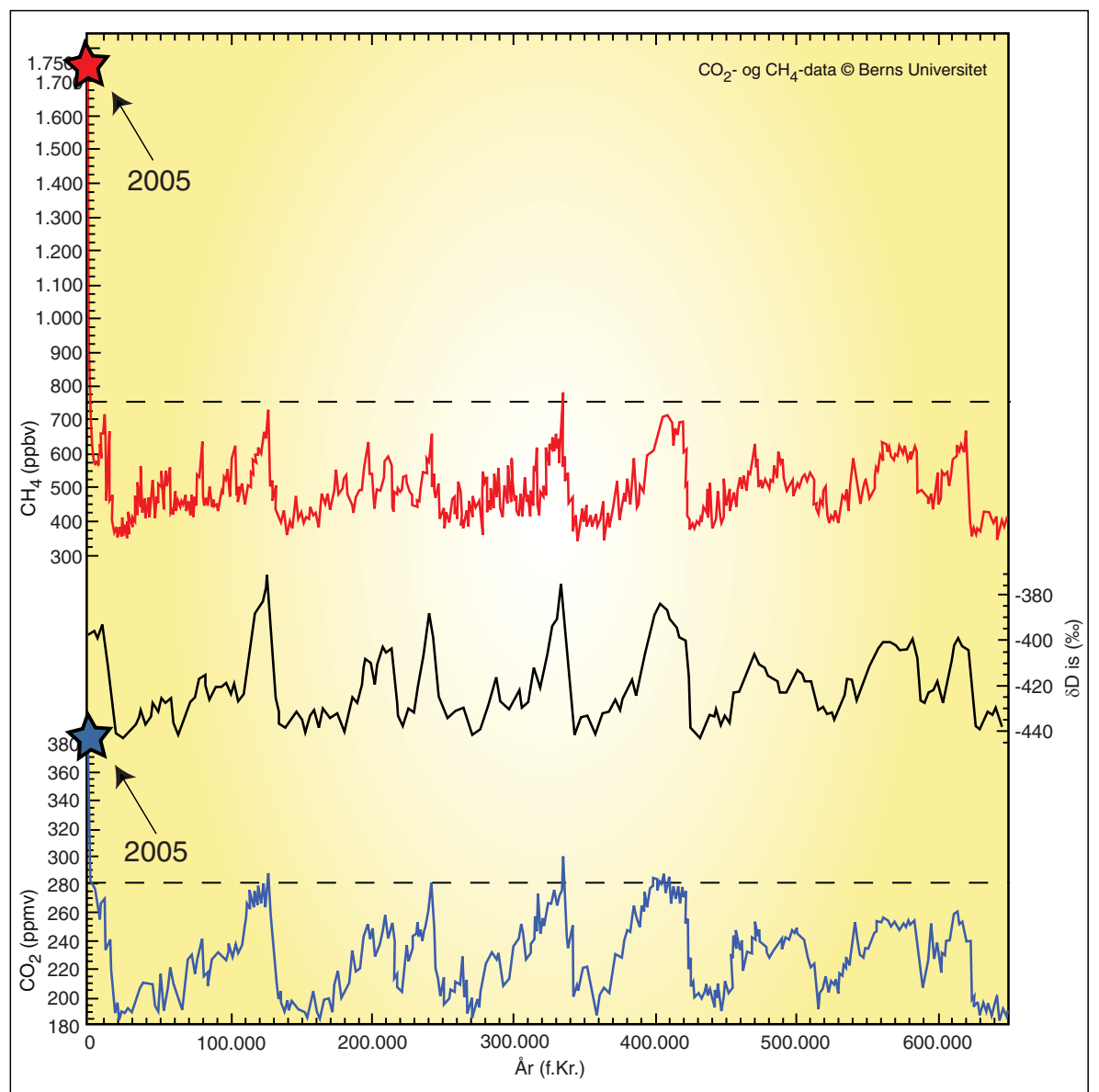

Figuren viser variationerne i $\mathrm{CO}_{2}$ (blå) og $\mathrm{CH}_{4}$ (rød) samt temperatur indikatoren (sort) for de sidste 650.000 år. Data er målt og sammenstilt fra forskellige lokaliteter på Antarktis (Vostock, Taylor og Epica projekterne). Bemcerk lavt $\mathrm{CO}_{2}$-og $\mathrm{CH}_{4}$-indhold under istider og modsat. Endvidere er de nutidige koncentrationer af $\mathrm{CO}_{2} \mathrm{og} \mathrm{CH}_{4}$ angivet med stjerner (se også tabellen s. 30). (Kilde: UVH modificeret efter og med tilladelse fra Thomas Stocker 2004. Copyright University of Bern, Schweiz.

Mange hundrede millioner menneskeog dyreliv vil gå tabt, da langt fra alle vil have muligheder for enten at rejse væk eller tilpasse sig de nye klimatiske forhold. Især Afrika vil blive hårdt ramt af tørke og mere ørkendannelse. Beregninger fra Met Office ved Hadley Centeret i England viser, at op mod en tredjedel af Jorden vil blive omdannet til ørken som følge af den globale opvarmning ved år 2100, men dette er sandsynligvis noget underestimeret, så dette bliver måske en realitet allerede inden for få årtier.

Iskernernes klimaarkiv og $\mathrm{CO}_{2}$

Klimaforskningen har længe fokuseret på udviklingen af den sidste interglacial- (Eemvarmetid) og glacialtid (Weichsel-Istid) for at forstå nutidens varmetid (Holocænet). Nyere iskerneforskning med resultater fra 
især Antarktis (Dome C, Epica-projektet) har gjort det muligt at vurdere $\mathrm{CO}_{2}-\mathrm{og} \mathrm{CH}_{4}$ indholdet $\mathrm{i}$ atmosfæren samt temperaturen godt 650.000 år tilbage $i$ tiden (se figuren ovenfor). Men vi skal helt tilbage i Eocænepoken for omkring 55 millioner år siden for at finde en temperatur, som er sammenlignelig ud fra den udvikling, som atmosfæren har i dag.

Vi ved i hvert fald med sikkerhed, at der er en klar sammenhæng mellem udviklingen af temperatur og $\mathrm{CO}_{2}$-indhold $\mathrm{i}$ atmosfæren igennem de sidste 7-8 istider og mellemistider. Hvad, vi også ved, er for de sidste 650.000 - måske 900.000 år, at istiderne og mellemistidernes $\mathrm{CO}_{2}$ - og $\mathrm{CH}_{4}$-indhold nøje har holdt sig inden for et bestemt interval, jf. tabellen s. 30. Klimaskiftene fra istid til mellemistid er hovedsageligt styret af variationer i jordens banegeometri omkring solen - forklaret ved den såkaldte "Milankovitch-teori" og suppleret af flere tilbagekoblingsmekanismer i klimasystemet. $\mathrm{Nu}$ er vi så kommet langt uden for det "kendte" klimainterval, hvori $\mathrm{CO}_{2}$ og $\mathrm{CH}_{4}$ varierer. Så hvordan og hvor hurtigt den "nye" klimaforandring vil finde sted, vides ikke, men svaret ligger måske begravet i de geologiske lagseriers hints og fossiler fra Eocæn og Kridttiden.

Hvis $\mathrm{CO}_{2}$-koncentrationen fortsat stiger med 2-3 ppm pr. år, så vil vi nå op i nærheden af Eocæn-tidens varme klima (global temperatur på ca. $23{ }^{\circ} \mathrm{C}$ ) med $\mathrm{CO}_{2}$-indhold langt over 500 ppm i løbet af nogle få årtier. Og går det helt galt, kan vi i løbet af måske de næste 100 år nå et niveau på over 1.000 ppm, svarende til måske Kridttidens helt specielle klimaer med globale temperaturer op mod de $28^{\circ} \mathrm{C}$.

Udviklingen af atmosfærens kuldioxidindhold vil måske forløbe anderledes, men det er yderst betænkeligt, at de sidste 45

\section{Metanhydrater}

Metanhydrater findes ofte i de marine sedimenterpå vanddybdertypisk mellem 200 til $1000 \mathrm{~m}$ (dvs. shelf-shelfslope), og hvor bundvandstemperaturen er omkring 2-5 grader. Dannelsen af metanhydraterne er forgået in-situ, dvs. under sedimentationsprocessen aflejres der døde organismer sammen med ler, silt og sandkorn, hvorunder omdannelsesprocessen af det organiske materiale fører til dannelsen af kulstofforbindelser i såkaldte metanhydrater som en slags iskrystalmasse. Disse er kun stabile inden for lave temperaturer og under et vist tryk. Ændres trykket eller temperaturen, vil kulstofforbindelserne primært nedbrydes til metangas.

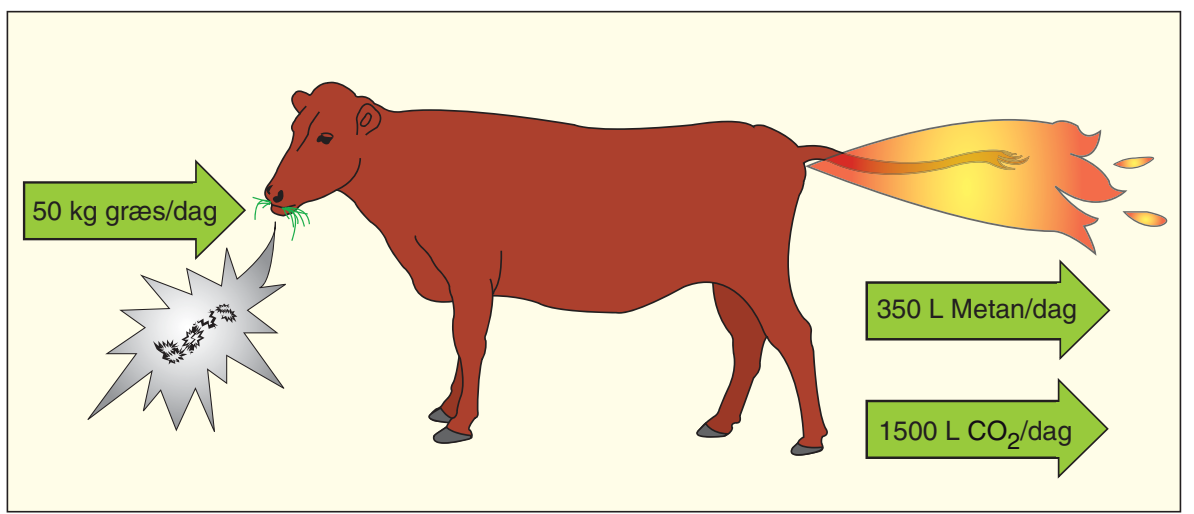

I New Zeeland er det, som et tiltag for at leve op til Kyoto-aftalen, blevet foreslået at lagge en prutte-skat på alt kvceg (mest køer og geder ), da de regnes for at bidrage med næesten 15 $\%$ af den globale metanudledning. Beregninger viser, at der ved daglig fordøjelse af ca. $50 \mathrm{~kg}$ grces produceres hhv. $350 \mathrm{~L} \mathrm{CH}_{4}$ og $1.500 \mathrm{~L} \mathrm{CO}_{2}$. I øvrigt menes verdens termitter ligeledes at udgøre et problem mht. $\mathrm{CH}_{4}$-bidrag. Hvem, der skal beskatte dem og hvordan, er dog ikke ncermere beskrevet. (Kilde: UVH modificeret efter news.bbc.co.uk, 20. juni 2003)

års målinger viser en årligt accelererende tendens. Sammenlignes udviklingen af $\mathrm{CO}_{2}-$ koncentrationen og temperaturen $\mathrm{i}$ iskerner for de sidste 650.000 år med stigningen $\mathrm{i}$ $\mathrm{CO}_{2}$-koncentrationen de sidste 50 år, sker stigningen nu omkring 200 gange hurtigere, end hvad der kan ses på kurverne. Første halvdel af det 20. århundrede var raten ca. 1-1,3 ppm/år, som så for alvor begyndte at røre på sig i 1980 og 1990'erne med 1,6 $\mathrm{ppm} / \mathrm{år}$. Den accelererende stigning forsatte og er nu steget til over 2 ppm/år fra år 2002. Fortsætter stigningen, vil $\mathrm{CO}_{2}$-koncentrationen nå over 500 ppm i 2050. De seneste tal fra Mauna Loa-observatoriet på Hawaii viser, at gennemsnittet for $\mathrm{CO}_{2}$-stigningsraten i 2006 kommer tæt på 3 ppm, og at koncentrationen vil ligge tæt på de $385 \mathrm{ppm} . \mathrm{CO}_{2}-$ niveauet er nu omkring $35 \%$ højere end år 1800-niveauet.

\section{Metan}

Foruden den stigende $\mathrm{CO}_{2}$-koncentration ses også en markant stigning i metan-koncentrationen. Metan $\left(\mathrm{CH}_{4}\right)$ er faktisk en meget farligere drivhusgas end $\mathrm{CO}_{2}$, da den er ca. 23 gange så "effektiv" en drivhusgas som $\mathrm{CO}_{2}$ (man taler om "det globale op- varmningspotentiale" set over 100 år). $\mathrm{CH}_{4}$ nedbrydes dog noget hurtigere $\mathrm{i}$ atmosfæren end $\mathrm{CO}_{2}$. Metan og kuldioxid har en "relativ levetid" på hhv. omkring 12-13 år og 50200 år. Undersøgelser af det eocæne klima antyder, at der også var et meget højt metanindhold i den daværende atmosfære, og at dette var en af hovedårsagerne til det meget varme klima.

Det er muligt, at en stigning i $\mathrm{CO}_{2}$-koncentrationen i Eocæntiden førte til stigning i den globale temperatur, som så medførte en omfattende stigning i metan-koncentrationen, hvilket så yderligere fik temperaturen til at stige voldsomt - en selvforstærkende proces så at sige (positiv tilbagekobling). Stigningen i metan-koncentrationen i den eocæne verden blev sandsynligvis udløst, da metanhydrater blev frigjort fra havbundssedimenterne. Dette er bl.a. indikeret af undersøgelser af eocæne fossilers kulstofisotop-forhold, hvor der er sporet et markant skift $\mathrm{i}$ det relative forhold mellem $\mathrm{C}^{13} \mathrm{og}$ $\mathrm{C}^{12}$. Metanhydraterne kunne også tænkes udløst ved undersøisk vulkanisme, så havbunden i større områder blev varmet op, og gasserne dermed frigjort. Eocæn vulkanisme skyldes især den begyndende åbning
Figuren viser de typiske dybder, hvor metanhydrater forekommer. (Grafik: UVH modificeret efter Alain Coustou og Henson, 2006)

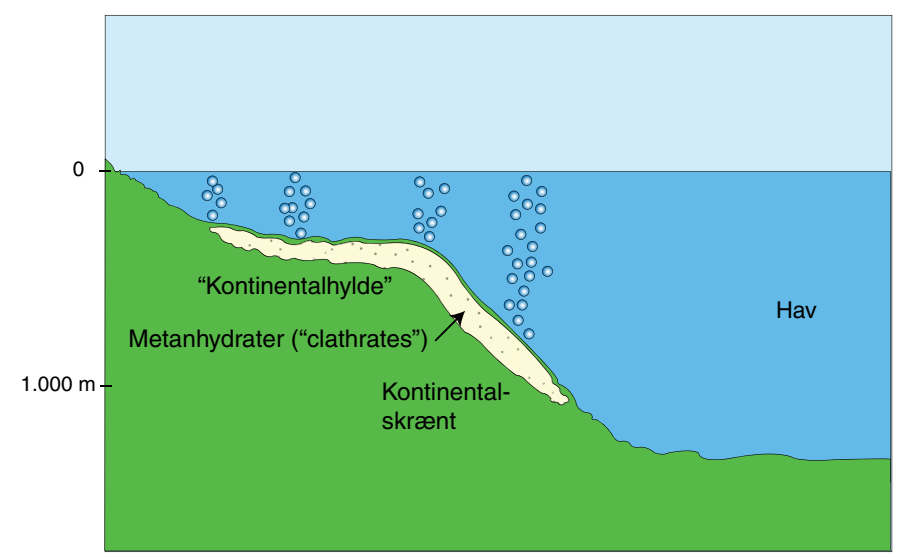




\section{Havniveaustigning}

Havniveaustigningen forårsages primært af to elementer: Termal ekspansion af havvandet, samt at der føres mere vandvolumen ud i verdenshavene ved afsmeltningen af iskapperne. Såfremt den globale havtemperatur stiger med $10^{\circ} \mathrm{C}$, vil dette føre til en global havniveaustigning på næsten $10 \mathrm{~m}$ blot ved termal ekspansion.

af Nordatlanten. En mere eksotisk teori for Eocænets høje indhold af metan går på, at en eller flere kometer slog ned og dermed berigede atmosfære/hydrosfæren på samme måde, som da kometen Shoemaker-Levy i 1994 hamrede ind i Jupiter og forårsagede voldsomme eksplosioner.

Trækker vi paralleller fra den eocæne verdens høje temperatur, høje $\mathrm{CO}_{2}-\mathrm{og}$ $\mathrm{CH}_{4}$-koncentrationer samt højt havniveau til nutidens stigende koncentrationer, er der et vigtigt, men ubehageligt perspektiv at bemærke følgende: Hvis temperaturen som følge af $\mathrm{CO}_{2}$-stigningen hæves, vil dette kunne starte frigørelsen af enorme mængder af især metan (og $\left.\mathrm{CO}_{2}\right)$ fra de naturligt bundne kulstofreservoirers i bl.a. Sibiriens store permafrosne tundra- og sumpområder og ikke mindst fra havbundens

\section{Positiv tilbage- kobling}

Den stigende globale opvarmning sker ikke alene ved, at drivhusgasserne forøges kraftigt, men skal også ses i lyset af, at kloden er kommet ind $\mathrm{i}$ flere positive tilbagekoblinger, som yderligere forstærker opvarmningen. Den vigtigste er nok is-albedo-tilbagekoblingen. Den virker ved, at en given opvarmning sætter gang $\mathrm{i}$ isafsmeltningen, som så nedsætter albedoen, hvilket medfører mindre reflekteret og mere absorberet varmeindstråling, som sætter gang i yderligere opvarmning osv. Der kører også andre positive tilbagekoblinger samtidigt fx:

Opvarmning $\rightarrow$ Tørke $\rightarrow$ flere skov/ hedebrande $\rightarrow$ mere $\mathrm{CO}_{2} \rightarrow$ mere opvarmning

Afbrænding af regnskovsområderne $\rightarrow$ mere $\mathrm{CO}_{2} \rightarrow$ mere opvarmning Stigende temperatur $\rightarrow$ decimering af plankton/dyr, som optager $\mathrm{CO}_{2} \rightarrow$ mere $\mathrm{CO}_{2} \rightarrow$ mere opvarmning

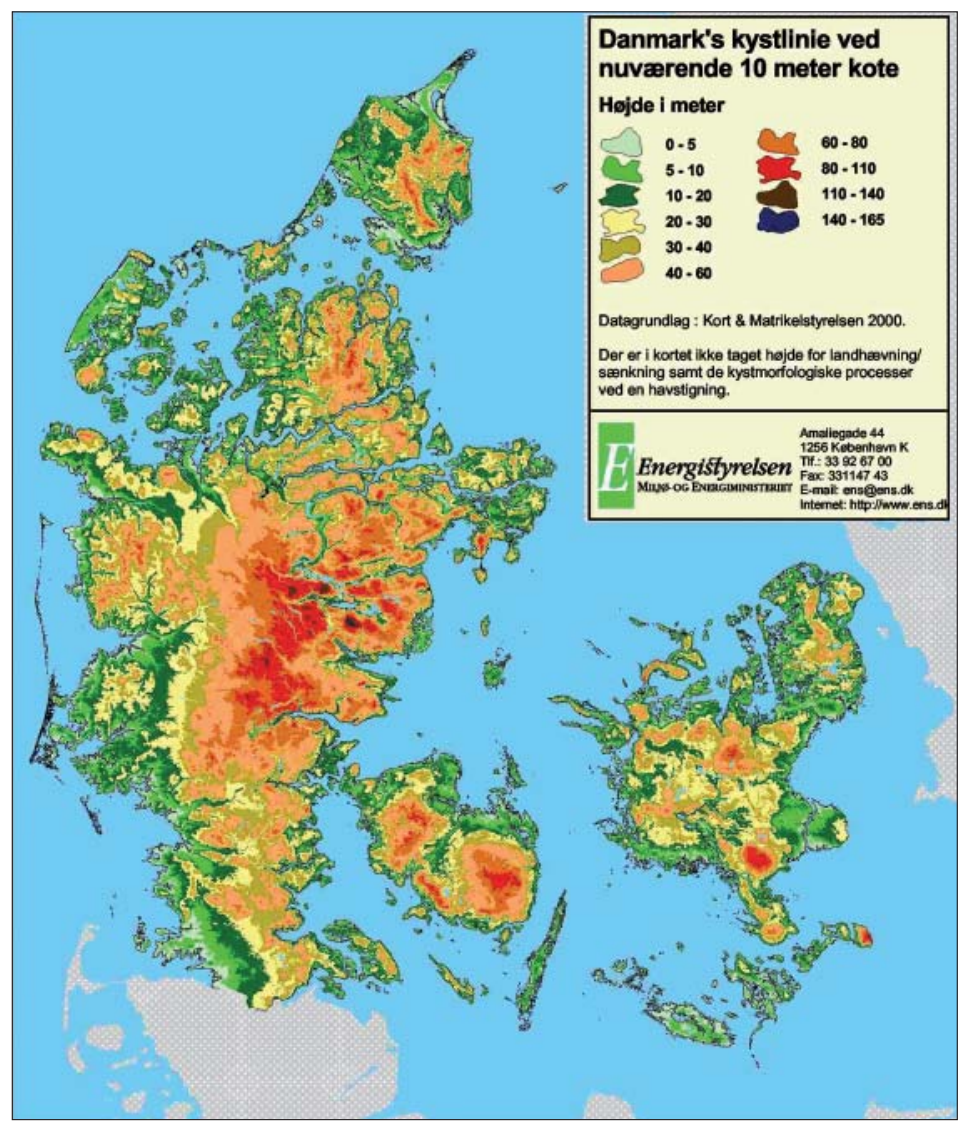

sedimenter. I sidstnævnte er det selvsagt havtemperaturen, som er afgørende. Denne selvforstærkende proces med frigørelse af drivhusgasser vil ikke være til at stoppe - en yderligere kraftig temperaturstigning vil blive konsekvensen. Tidsperspektivet og temperaturtærsklen for, hvornår denne proces vil kunne gå i gang, er ikke kendt men ligger muligvis inden for hhv. få år/årtier til måske flere hundrede år samt inden for 2-4 ${ }^{\circ} \mathrm{C}$. Det afhænger helt af, hvor hurtigt atmosfæretemperaturen kan forplante sig til vandtemperaturen i havstrømmene.

IPPC's scenarier (2001) for temperaturstigning og $\mathrm{CO}_{2}$-stigning skitserer en stabilisering på hhv. $2^{\circ} \mathrm{C}$ og $550 \mathrm{ppm} \mathrm{CO}$ omkring år 2050. Måske er dette mål opnåeligt, hvis nødbremsen for $\mathrm{CO}_{2}$-udledningerne hamres i nu, men hvis det har førnævinte konsekvenser for udviklingen af metangasfrigørelse, så er det jo næsten lige meget - eller lige lidt! Flere klimaforskere mener, vi er tæt på eller allerede har passeret det såkaldte "point of no return" - så indsats mod yderligere forværring må undgås jo før desto bedre.

Den omfattende dyrkning af ris og visse andre afgrøder bidrager også betydeligt med metangas. Verdens omfattende kvæghold tilfører også et væsentligt bidrag af metangas, når dyrene nedbryder de planter, som ædes. I efteråret 2006 drøftede man seriøst i den newzealandske regering at indføre den såkaldte "flatulens-skat" på kvæg fx køer og får, idet disse bidrager med ca. $15 \%$ af det samlede globale metan-udslip hvert år. Ikke overraskende førte udmeldingen om "prutteskat" til store protester. Metan-niveauet er nu omkring $150 \%$ højere end før år 1800 , og antallet af kvæg menes at være omkring 2,5-3 milliader (det er mange "vinde" dagligt). Desuden er menneskeheden jo selv vokset fra ca. 1 mia. til over 6 mia. på de 200 år, og vi "udveksler" også $\mathrm{CH}_{4}$ og $\mathrm{CO}_{2}$ med omgivelserne.

\section{Isafsmeltning og havniveaustigninger} IPPC-cenariets rapport fra 2001 forudsiger en global temperaturstigning mellem 1,4 og $5,8^{\circ} \mathrm{C}$ samt en global havspejlsstigning mellem 9 og $88 \mathrm{~cm}$ ved år 2100. Før den 4. IPPC-klimarapport udsendes i foråret 2007, er der kommet mere "præcise" tal og vurderinger på bordet. $\mathrm{Nu}$ menes det med rimeligt stor sandsynlighed, at temperaturen stiger mellem 2 og $4,5^{\circ} \mathrm{C}$, og at $3{ }^{\circ} \mathrm{C}$-scenariet ser ud til at være mest sandsynligt, såfremt vi fortsætter ufortrødent med udledningerne. De seneste års observationer af gletscher-retræter fra hele kloden, særligt fra Grønland, viser hurtigere afsmeltninghastigheder, end flere modeller forudsiger - observationerne giver grobund for alvorlige spekulationer om, hvorvidt IPPC-havniveaustigningscenarier er alt for optimistiske. En halv meters havniveaustigning menes at være realistisk inden 2050 ifølge amerikanske forskere fra Columbia University, New York. Det samme kommer Stefan Rahmstorf til fra universitetet i Potsdam. De mener endvidere, at havniveauet kan stige op til 1,40 m ved udgangen af år 2100 . 
Noget tyder i hvert fald på, at modellerne og naturen ikke helt fortæller samme historie - måske skal der justeres med en faktor 10 i IPPC-scenarierne, så det hedder 90 $-880 \mathrm{~cm}$ havniveaustigning inden år 2100 ? Nyeste modelscenarier om isafsmeltning ved Nordpolen viser, at denne sandsynligvis er væk inden år 2040 ifølge et forskerhold fra National Center for Atmospheric Research (NCAR), University of Washington og McGill University.

Ser man på de palæoklimatiske vidnesbyrd fra havbundskerner, iskerner etc., har havniveauet og ikke mindst temperaturen undergået nogle ret hurtige skift inden for det spektrum, som man anser som "normalen". Fx steg temperaturen med $16^{\circ} \mathrm{C}$ inden for ca. 40 år i slutningen af sidste istid. Man kan gyse ved tanken om, hvad der kan ske, når vi "pludselig" lægger $35 \%$ mere $\mathrm{CO}_{2}$ og $150 \%$ mere $\mathrm{CH}_{4}$ ind i systemet. Det er ikke kun havniveauet, som har ændret sig - også havstrømmene (den termohaline cirkulation) har ændret sig markant i gennem de sidste 650.000 års klimasvingninger - herunder golfstrømmen. En teori er, at golfstrømmen går helt i stå som følge af opvarmningen og afsmeltningen af de store iskapper, og at man dermed får meget koldere klima i NVEuropa som konsekvens. Nogle forskere anser dette som en realitet, mens andre mener, at den i forvejen kraftige opvarmning

\begin{tabular}{|c|c|c|c|}
\hline Tidsrum & $\mathrm{CO}_{2}$-koncentration (ppm) & $\mathrm{CH}_{4}$-koncentration (ppm) & Havniveau (m) \\
\hline $\begin{array}{l}\text { Glacialer-interglacialer. } \\
\text { De sidste } 650.000 \text { år }\end{array}$ & $180-280$ & $0,350-0,790$ & -120 til 0 \\
\hline 1780 & 280 & 0,750 & 0 \\
\hline 1930 & 315 & 0,950 & $+0,1$ \\
\hline 2005 & 380 & 1,750 & $+0,35$ \\
\hline 2050 & $+500(?)$ & $+3(?)$ & $+0,5-1,5(?)$ \\
\hline 2100 & $+1.000(?)$ & $+5(?)$ & $+5(?)$ \\
\hline Eocæn (55-34 mio.) & $500-2.000(?)$ & $+5(?)$ & $+100(?)$ \\
\hline Kridt (144-65 mio.) & $800-2.500(?)$ & $+5(?)$ & $+2-300(?)$ \\
\hline
\end{tabular}

* Bemcerk, at Kridttidens havniveau var en kombination af meget stor tektonisk aktivitet samt det varme klima med høj $\mathrm{CO}_{2}$-koncentration. Den tektoniske aktivitet skubbede forenklet set havbunden højere op, hvilket så gav en relativt højere vandstand globalt set. Det "reelle" havniveau kun forårsaget af det varmere klima var formentlig kun ca. +150 m! (Grafik: UVH modificeret efter Henson 2006 og Ruddiman 2003; de røde tal er gisninger)

vil udligne den varmevirkning, som ellers vil komme fra golfstrømmen og resultatet dermed går lige op - altså ingen kulde, hvis golfstrømmen sættes i stå.

Men nu er vi langt ud over, hvad vi kan forvente inden for normalen, så vi må nok alene af den grund forberede os på nogle dramatiske ændringer de kommende årtier. Inden for de sidste par år er det set, hvorledes at den ene temperaturrekord, såvel i luften som i havet (mest de varme forstås), slår den anden rundt om på kloden - og mere ekstreme nedbørshændelser og tørker gentages oftere, end statistikken kan forudsige.

Der er klare tegn på, at Grønlands indlandsis smelter, og sker dette helt, vil havniveauet stige med ca. $7 \mathrm{~m}$. Ydermere er der klare tegn på, at havisen over Nordpolen samt store is-shelf-områder ved Antarktis er under afsmeltning. Sker denne afsmeltning fuldstændigt, vil det globale havspejl kunne stige med ca. $27 \mathrm{~m}$. Dette vil unægteligt have voldsomme konsekvenser for både mennesker, fauna og flora. Store øgrupper, lavtliggende landområder fx Bangladesh, de fleste Stillehavs-øgrupper og Holland vil enten blive totalt oversvømmet eller reduceret $i$ en sådan grad, at meget liv vil gå til grunde. De økonomiske aspekter ved dette er ligeledes uoverskuelige. Ifølge rapporten om de økonomiske konsekvenser ved klimaændringerne fra den britiske regering, som 
blev offentliggjort i oktober 2006 (Sternrapporten), vil det koste op mod 40.000 milliarder kroner for verdenssamfundet at afværge katastrofen. I fald vi ikke gør noget $\mathrm{nu}$, kan regningen nemt blive mere end 20 gange så høj. Hertil kommer et uvurderligt tab af menneskeliv og biodiversitet. Havniveauet vil endvidere kunne stige helt op mod $80 \mathrm{~m}$ mere end nu, såfremt at alt is ved Grønland, nord- og sydpolerne er smeltet; konsekvenserne er i den grad fatale.

\section{Prognose:}

Behovet for vækst (dvs. mere energi) og økonomisk udvikling er stigende på verdensplan, hvilket er synonymt med en forsat og uformindsket $\mathrm{CO}_{2}$-udledning. Ifølge IEA (Internationale Energi Agentur) vil både behovet for energi og $\mathrm{CO}_{2}$-udledningen kunne stige med op mod $50 \%$ i år 2030, såfremt udviklingen/væksten på verdensplan fortsætter i det samme spor som nu - og her er det især Kina, Indien og USA, der står for hovedparten. I øjeblikket udledes der ca. 8 GT kulstof/år, og dette niveau og de foregående data matcher en prognosekurve fra IPCC (2001), som ender på næsten 16 GT kulstof/år i år 2050.

Klimaskræk-scenariet "Buissness as usual" vil da nemt blive til virkelighed, og temperaturen vil løbe løbsk med en stigning på 5-6 ${ }^{\circ} \mathrm{C}$ inden år 2100. Det er desværre ofte sådan i politik og lovgivning, at der skal lig på bordet, før der kommer handling og interesse. I tilfældet med den globale opvarmning er der allerede masser af lig - fx hedebølgen i 2003 som kostede næsten 40.000 mennesker livet bare i Europa, hertil orkanerne og oversvømmelser i mellem Amerika og Asien (de sidste 10 år) kostede også rigtig mange menneskeliv.

Skarpe advarsler kom nyligt fra FN's generalsekretær om den manglende vilje og handling mod at gøre noget seriøst ved klimaproblemet, men indtil videre styrer vi mod "Buissness as usual" og altså ingen større afværgehandlinger. Men kan vi så gribe ind, og i givet fald - hvad skal vi gøre? Den umiddelbare og enkle løsning er jo hurtigst muligt at overgå til sol, vind og vandenergiformer, som er "rene". Men hvis opvarmningen skal bremses hurtigt, er der også spændende forslag om "rumparasoller", som blokerer solindstrålingen med temperaturfald til følge. Kan "moder natur" så ikke hjælpe med en istid - desværre nok ikke i nærmeste fremtid, da "Milankovitchteoriens" fremskrivninger af forholdene for kommende istider tidligst ser gunstige ud om 50.000 år.

\section{Kulsort outtro}

Jordklodens reaktion på det voldsomme antropogene kuldioxid- og metan-udslip vil komme i løbet af de næste årtier og har allerede varslet sin dystre ankomst. Fortsætter vi ufortrødent med at udlede $\mathrm{CO}_{2}$ i samme tempo som nu - så kommer der for alvor til at ske forandringer - en veritabel klima-deroute er indledt og synes nu med stor sandsynlighed at blive helt uundgåelig. Måske vil menneskeheden komme til at opleve en decimering så voldsom, at middelalderens "sorte død" til sammenligning synes at være en lille sommerforkølelse. Man kan håbe, at flere ansvarlige politikere snart vågner op og for alvor sætter klimakatastrofen på dagsordnen, så vi i det mindste forsøger at afbøde det værste, som er i sigte.

\section{Kilder og inspiration:}

Ruddiman 2003: Past and future climate Ruddiman 2005: Plages, Plows and petroleum

Lovelock 2006: The revenge of Gaia Henson 2006: The rough guide to climate change

Links:

www.ipcc.ch

www.noaa.com

\section{Kort nyt}

Kystsikring for 35 mio. kr.

Opfinderen Poul Jakobsen fra Skagen er startklar, hvis Folketingets trafikudvalg siger ja til at sikre den jyske vestkyst med drænrør. Den nordjyske opfinder arbejder på et endeligt tilbud, der ifølge Poul Jakobsen kan udføres for under 35 mio. kr., og som skal i givet fald udføres i samarbejde med den største entreprenørvirksomhed i Holland, BAM Group NV.

Opfinderen har haft problemer med at blive anerkendt af Kystdirektoratet for effekten af drænrørene. Direktoratet stolede mere på de traditionelle metoder i form af sandfodring og høfdeanlæg, hvoraf sidstnævnte er temmeligt bekostelige, men i en ny og længe ventet rapport udtaler direktoratets eksperter, at Poul Jakobsens drænrør kan have en positiv virkning på kysterne.

$J P / U V H$

\section{Hvorfor sprænges frosne sten ?}

Hvis man efterlader en flaske vin i fryseren lidt for længe, springer flasken. Det skyldes, at vinen (vand) udvider sig $9 \%$ fra flydende til fast form og derved påvirker flasken med et kolossalt tryk. Derfor kunne man også godt tro, at sten springer, når vandet $\mathrm{i}$ dem fryser til is. Men sådan er det ikke helt. For nylig har Murton, Peterson og Ozouf påvist, at en anden proces er ansvarlig for, at sten springer, når det bliver koldt.

Det er ganske rigtigt, at vand udvider sig $9 \%$, når det fryser, men med mindre stenen er total mættet med vand eller frossen fra alle sider, vil isen have mulighed for at flyde ind i tomme porer eller undslippe gennem den ikke-frosne side. Den udbredte opfattelse af, at frysende vand kan åbne en sprække i stenen som en kile, er sikkert også ubetydelig i naturen, eftersom vandet kan sive ud af revnen og isen i revnen kan skubbe sig selv ud.

En mere sandsynlig forklaring involverer frost, men uafhængigt af vands udvidelse ved frysepunktet. Nylige eksperimenter har nemlig påvist, at stenen ikke springer ved vands frysepunkt på $0{ }^{\circ} \mathrm{C}$, men ved endnu lavere temperaturer på -3 til $-6^{\circ} \mathrm{C}$. Og det er ikke kun vand, der kan få sten til at springe. Også væsker, der trækker sig sammen (i modsætning til vand, der udvider sig), kan få sten til at springe. Det viser sig, at stenen sprænges som følge af is-linser (kendt som segregations-is), der dannes og opretholdes af vand fremført langs en tynd vandfilm. Molekylære kræfter mellem stenoverfladen i revnen, is og vand fastholder vandfilmen og skaber det høje tryk mellem stenen og isen, der får stenen til at springe. Som temperaturen aftager, bliver vandfilmen tyndere og vandforsyningen derfor mindre, men det maksimalt opnåelige tryk bliver større.

Denne nye forståelse giver dybere indsigt i frost-induceret forvitring og de basale processer, der har dannet landskabet i kolde egne, ikke bare på Jorden, men også planeter, som fx Mars.

Science, Nov. 2006/TH 